\title{
New endoscopic technique for uncontrollable bilious vomiting after gastrojejunal surgical bypass
}

Gastrojejunal Billroth II or single Rouxen-Y reconstructions that create a defunctionalized loop, are usually performed to treat patients with unresectable periampullary tumors [1,2]. The main adverse effect is bile reflux $[3,4]$, with irritation of the gastric mucosa, that can generally be controlled with prokinetic drugs [1-4]. However, if the symptoms are severe, a redo surgery is the only available option described in the literature [1-4].

A 70 year-old man presented with copious vomiting of bile associated with inability to eat due to severe acute alkaline gastritis. Because of an inoperable pancreatic head tumor (with liver metastases), the patient had undergone biliojejunal and gastrojejunal surgical bypasses on a single Roux-en-Y defunctionalized loop 1 month earlier. (The surgeons had begun to create a Roux-en-Y reconstruction. However during the operation they had decided to use the biliary loop for the gastrojejunal anastomosis also. Thus they had created a single isolated Roux-en-Y loop and functionally a Billroth II reconstruction.)

From the earliest postoperative days the patient began to vomit bile increasingly because of gastroparesis linked to severe acute alkaline injury of the gastric mucosa.

In agreement with the surgeons, we decided to propose a new endoscopic technique to the patient for palliation of the clinical problem.

First, we placed a 7-Fr nasojejunal tube in the efferent part of the Roux-en-Y loop under both endoscopic and fluoroscopic view so that we could identify the efferent loop using endoscopic ultrasound.

Then, we introduced a linear echoendoscope (EG-3870 UTK; Pentax, Hamburg, Germany) into the afferent part of the loop (containing the biliary anastomosis). After dilating the efferent part (the portion after the gastrojejunal anastomosis) with physiological solution, we were able to locate it endosonographically. We failed to perform an endoscopic enteral bypass with our previously described usual technique (using a cystoenterostome and a fully covered lumen-apposing metal stent [LAMS], $16 \mathrm{~mm} \times 20 \mathrm{~mm}$ ) [5] having lost the correct position because of loose intestinal contact caused by ascites. At the end of this first attempt, we placed some endoclips to close the intestinal perforation. The following day we used the Hot Axios Stent and Electrocautery Enhanced Delivery System (Boston Scientific, Marlborough, Massachusetts, USA) to pass from the afferent to the efferent portion and we created a fixed new bridge between them using a LAMS (diameter 15-24 mm, length $10 \mathrm{~mm}$ )

\section{$(\triangleright$ Video 1$)$}

The patient had an immediate resolution of symptoms and a prompt improvement in terms of quality of life with 3 months of follow-up.

This new endoscopic technique was used as a rescue therapy in a patient with low life expectancy and poor general condition in order to avoid a surgical re-operation. We have begun to verify this first result with a prospective study in selected patients.

Endoscopy_UCTN_Code_TTT_1AS_2AG

\section{Competing interests}

M. Mutignani is proctor for Boston Scientific.

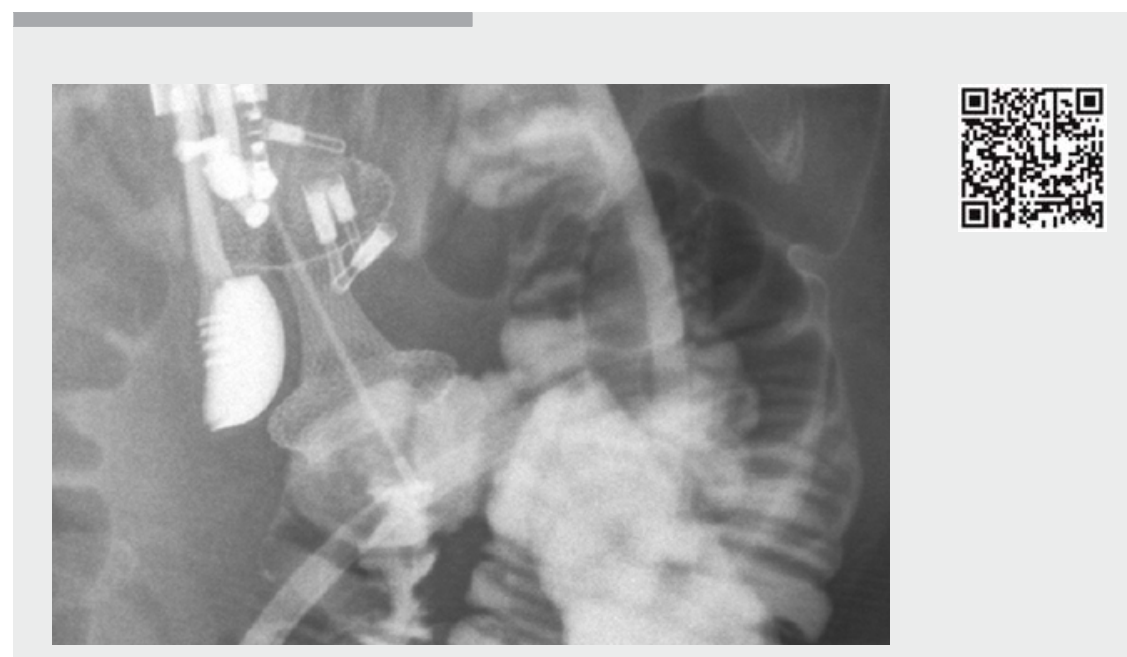

Video 1 In a patient with a gastrojejunal bypass and copious vomiting of bile, enteroenteral stenting was performed to allow bile to flow directly from the afferent to the efferent portion of the gastrojejunal derivation, thus bypassing the gastrojejunal anastomosis. 
Massimiliano Mutignani, Edoardo Forti, Francesco Pugliese, Alberto Tringali, Marcello Cintolo, Lorenzo Dioscoridi

Diagnostic and Interventional Digestive Endoscopy, Niguarda Ca-Granda Hospital, Milan, Italy

Corresponding author

Massimiliano Mutignani, MD

Endoscopy Unit Niguarda Ca-Granda

Hospital, Piazza dell'Ospedale Maggiore 3,

20162 Milano, Italy

Fax: +39-02-64442911

massimiliano.mutignani@ospedaleniguarda. it

\section{References}

[1] Zong L, Chen P. Billroth I vs Billroth II vs Roux-en-Y following distal gastrectomy: a meta-analysis based on 15 studies. Hepatogastroenterology 2011; 58: 1413-1424

[2] Sitarz R, Maciejewski R, Polkowski WP et al. Gastroenterostoma after Billroth antrectomy as a premalignant condition. World J Gastroenterol 2012; 18: 3201-3206

[3] Zobolas B, Sakorafas GH, Kouroukli I et al. Alkaline reflux gastritis: early and late results of surgery. World J Surg 2006; 30: 1043 1049

[4] Cui LH, Son SY, Shin HJ et al. Billroth II with Braun enteroenterostomy is a good alternative reconstruction to Roux-en-Y gastrojejunostomy in laparoscopic distal gastrectomy. Gastroenterol Res Pract 2017. DOI: 10.1155/ 2017/1803851. Article ID 1803851

[5] Mutignani M, Manta R, Pugliese F et al. Endoscopic ultrasound-guided duodenojejunal anastomosis to treat postsurgical Roux-en-Y hepaticojejunostomy stricture: a dream or a reality? Endoscopy 2015; 47 (Suppl. 01): E350-E351

\section{Bibliography}

DOI https://doi.org/10.1055/s-0043-113554

Published online: 18.7.2017

Endoscopy 2017; 49: E225-E226

(c) Georg Thieme Verlag KG

Stuttgart · New York

ISSN 0013-726X

\section{ENDOSCOPY E-VIDEOS}

https://eref.thieme.de/e-videos

回回 Endoscopy E-Videos is a free

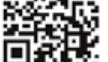
access online section, reporting on interesting cases and new techniques in gastroenterological endoscopy. All papers include a high quality video and all contributions are freely accessible online.

This section has its own submission website at

https://mc.manuscriptcentral.com/e-videos 